\title{
DEVELOPMENT OF COLLECTIVE ACTIVITY OF SPECIALIZED ASSISTANT SCHOOL STUDENTS ON THE BASIS OF DIDACTIC GAMES IN MATHEMATICS
}

\author{
M.P. Khamidova
}

Associate Professor Tashkent State Pedagogical University Tashkent, Uzbekistan

\section{ABSTRACT}

Teaching math helps students with intellectual disabilities develop cognitive skills such as cognition, memory, thinking, imagination, and mastery of mathematical knowledge and skills. Corrective work aimed at developing mathematical knowledge, skills and abilities allows to perform mental operations such as analysis, synthesis, comparison, generalization, concretization.

KEYWORDS:- Mathematics, didactic games, development, specialized auxiliary schools.

\section{INTRODUCTION}

We will mobilize all the forces and capabilities of our state and society to ensure that our young people have a high intellectual and spiritual potential for independent thinking, to develop and be happy as people who are not emptyhanded in any field to their peers around the world. kidladi SH.Mirziyoyev.

Speaking about the upbringing of the younger generation, Abdurauf Fitrat said: I would like each of us, especially our sons and daughters, to follow the advice of their parents, "said SH. Mirziyoyev [1].

Based on the requirements of the "Concept of Special Education", it is important to work on the education of children with intellectual disabilities, their adaptation to social life and the development of their mathematical knowledge.

\section{THE MAIN RESULTS AND FINDINGS}

The main general educational task of mathematics education is to teach mentally retarded students the mathematical knowledge and skills necessary for their future careers and daily lives, and to form the ability to apply these knowledge and skills throughout their lives.

These are the main tasks that should be used in determining the tasks of teaching mathematics to secondary school students. Like any other subject, mathematics must address educational, pedagogical, and practical tasks.

Mathematical materials and work with them teach students to think logically, to express themselves clearly and fluently in oral and written speech.

The concreteness of the thinking of mentally retarded students, the lack of ability to 
CURRENT RESEARCH JOURNAL OF PEDAGOGICS 2(11): 134-137,

November 2021 DOI: https://doi.org/10.37547/pedagogics-crjp-02-11-25

ISSN 2767-3278

(C)2021 Master Journals

Crossref do: 81 Google

Accepted 25th November, 2021 \& Published 30 ${ }^{\text {th }}$ November, 2021

generalize the observed phenomena, leads to the fact that the concept of numbers and arithmetic develops very slowly in these students. It doesn't develop well even in the first grade. The success of children with intellectual disabilities in learning mathematics depends on their characteristics and the difficulties they face in mastering mathematical concepts. Therefore, the use of different methods in the development of mathematical knowledge of mentally retarded children gives good results. These include educating the younger generation, focusing on children with special educational needs, and improving teaching methods and techniques.

In mentally retarded children in the first grade, the problem of constructing their ideas about numbers, the concept of numbers, and the properties of a series of natural numbers is very complex. It can be solved only through the extensive use of visual aids, taking into account the individual capabilities of each child, his previous experience.

The concreteness of the thinking of mentally retarded students, the lack of ability to generalize the observed phenomena, leads to the fact that the concept of numbers and arithmetic develops very slowly in these students.

It should be noted that these problems can be solved only if students work on the basis of various didactic games.

We tried to find a solution to this problem, taking into account the fact that the development of cognitive activity of children with intellectual disabilities on the basis of didactic games has a positive effect.

Didactic games are based on activating and accelerating student activity. They play an important role in identifying and implementing practical solutions to realize and develop the creative potential of the student.

Didactic games, as part of intellectual methods, lead the student to use their inner potential, to think, to think freely, to communicate, to be creative.

In particular, it develops the environment, interest in life, challenges, how to overcome obstacles and develop critical thinking skills.

Indeed, today the implementation of educational work in our country has become a priority of state policy. A number of documents have been adopted in this area, and some experience has been gained.

The psychological characteristics of the problem of developing students' cognitive activity are aimed at overcoming these problems. The development of a new model of personality, recognized in the "National Training Program", from the development trends of the young generation in the educational process to the adoption of new learning technologies by the child and the impact on his intellectual abilities. Psychological approach to the principles of spiritual perfection in schools requires the application of the most advanced and modern forms of teaching.

Developing cognitive skills in students with intellectual disabilities is also a complex process. Therefore, in the educational process, it is necessary to take into account their individual characteristics and organize work with a special approach to them. The use of didactic games in mathematics lessons helps to overcome the shortcomings of the above-mentioned cognitive activities. The effectiveness of a teacher's work is measured by the effectiveness of the knowledge, skills, and competencies acquired by each individual student. Therefore, the correct organization of the teacher's mathematics lessons, the appropriate use of didactic games in the classroom will help to overcome the shortcomings in the development of mentally retarded students. 
CURRENT RESEARCH JOURNAL OF PEDAGOGICS 2(11): 134-137,

November 2021 DOI: https://doi.org/10.37547/pedagogics-crjp-02-11-25

ISSN 2767-3278

(C)2021 Master Journals

Crossref do: 81 Google

Accepted 25th November, 2021 \& Published 30 ${ }^{\text {th }}$ November, 2021

Didactic games allow children to work together as a whole class, to be self-directed, to concentrate, to be tidy, to understand quickly, and to answer questions quickly. will be of great importance in the formation of giving and other educational qualities. Such didactic games reduce the student's ability to lie down with the teacher. As a result, the teacher becomes a friend to the child, a partner in solving this or that problem. The main purpose of any didactic game used in mathematics is educational.

\section{Conclusion}

Focusing on and developing cognitive processes in the intellectual development of students helps to teach them to think independently.

Our research has shown that the use of didactic games in the development of cognitive activity of mentally retarded students, especially in mathematics, has been shown to have positive results.

Didactic games are an important tool in developing students' mental levels.

We found it necessary to develop guidelines for the development of cognitive activity of students of specialized secondary schools on the basis of didactic games in mathematics lessons:

- Play activities are aimed at solving the educational goals and objectives of the topics covered in the program;

- The use of games in mathematics helps students to engage in communication, that is, to acquire a communicative culture;

- A focus on the study of the value system that is important to humanity, especially social, spiritual, cultural, national and universal values;

- Development of mathematical concepts in game participants;
- Helps to overcome difficulties in mastering mathematics in life and play;

- The game provides an opportunity to acquire behavior in accordance with social norms, to eliminate shortcomings in the acquisition of mathematical concepts;

- The game is logical in structure and suitable for mentally retarded students;

- Skillfully summarize the results of the game and link them to the results achieved.

\section{REFERENCES}

1. Mirziyoyev Sh. "Together we will build a free and prosperous state of democratic Uzbekistan." T: “Uzbekistan" - 2017

2. Ek V.V. Teaching mathematics to students of elementary grades of special (correctional) educational. Institutions of the VIII type: a manual for the teacher / V.V. Eq. - 2nd ed., Rev. - M .: Education, 2005

3. Sagatov M.I., Xamidova M.P. Special methods of teaching mathematics. $\mathrm{T}$ : Nodirabegim, 2021

4. Perova M.I. Methods of teaching mathematics in a special (correctional) school of the XIII type: Textbook. For stud. defect, fac. ped. universities. - M .: Humanit. ed. Center VLADOS, 2001

5. DJURAEVA, N. (2021). ATTITUDE TO WOMEN IN UZBEKISTAN IN PUBLIC POLICY AND STRATEGY. Journal of Information and Computer Science, (1), 52-56.

6. Garet, M. S., Porter, A. C., Desimone, L., Birman, B. F., \& Yoon, K. S. (2001). What makes professional development effective? 
CURRENT RESEARCH JOURNAL OF PEDAGOGICS 2(11): 134-137,

November 2021 DOI: https://doi.org/10.37547/pedagogics-crjp-02-11-25

ISSN 2767-3278

(C)2021 Master Journals

Crossref dof Google

Accepted 25th November, 2021 \& Published 30th November, 2021

Results from a national sample of teachers. American educational research journal, 38(4), 915-945.

7. Dalibaevna, N. D. (2021). GENDER EQUALITY IS ONE OF THE REQUIREMENTS OF A DEVELOPED SOCIETY. CURRENT RESEARCH JOURNAL OF HISTORY (2767-472X), 2(06), 82-85.

8. McDonald, M., Kazemi, E., \& Kavanagh, S. S. (2013). Core practices and pedagogies of teacher education: A call for a common language and collective activity. Journal of teacher education, 64(5), 378-386.

9. Dalibaevna, N. D. (2020). THE PLACE AND ROLE OF WOMEN IN SOCIETY IN THE PRE-ISLAMIC PERIOD. INTERNATIONAL JOURNAL OF DISCOURSE ON INNOVATION, INTEGRATION AND EDUCATION, 1, 58-65.

10. Ball, D. L., Sleep, L., Boerst, T. A., \& Bass, H. (2009). Combining the development of practice and the practice of development in teacher education. The Elementary School Journal, 109(5), 458-474. 